\title{
Cleavage of the main carbon chain backbone of high molecular weight polyacrylamide by aerobic and anaerobic biological treatment
}

\author{
Wenzhe Song ${ }^{\text {a, b }}$, Yu Zhang ${ }^{\text {a, b, * , Yingxin Gao }}{ }^{\text {a, b }}$, Dong Chen ${ }^{\text {a, b }}$, Min Yang a, b \\ a State Key Laboratory of Environmental Aquatic Chemistry, Research Center for Eco-Environmental Sciences, Chinese Academy of Sciences, Beijing, 100085, \\ China \\ ${ }^{\mathrm{b}}$ University of Chinese Academy of Sciences, Beijing, 100049, China
}

\section{H I G H L I G H T S}

- PAM over $2 \times 10^{7}$ Da was reduced to less than one-third of its original size after biological treatment.

- Both aerobic and anaerobic treatment were effective in the hydrolysis of large molecular weight PAM.

- Thermophilic anaerobic treatment was more efficient in degrading PAM.

\section{A R T I C L E I N F O}

\section{Article history:}

Received 23 April 2017

Received in revised form 13 September 2017

Accepted 16 September 2017

Available online 18 September 2017

Handling Editor: W Mitch

\section{Keywords:}

Polyacrylamide

Biodegradability

Produced water

Enhanced oil recovery

\section{G R A P H I C A L A B S T R A C T}

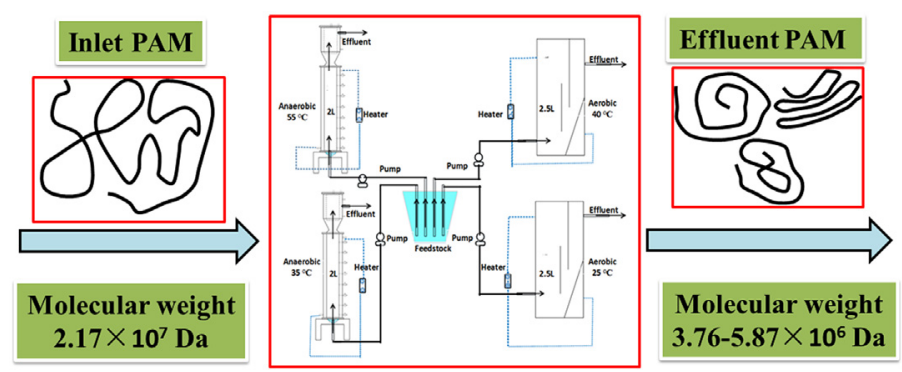

\begin{abstract}
A B S T R A C T
High molecular weight partially hydrolyzed polyacrylamide (PAM) can be bio-hydrolyzed on the amide side group, however, solid evidence regarding the biological cleavage of its main carbon chain backbone is limited. In this study, viscometry, flow field-flow fractionation multi-angle light scattering (FFF-MALS), and attenuated total reflectance-Fourier transform infrared (ATR-FTIR) analysis were used to investigate the biodegradability of PAM with a nominal molecular weight of $2 \times 10^{7} \mathrm{Da}(\mathrm{Da})$ in two suspended aerobic $\left(25\right.$ and $40{ }^{\circ} \mathrm{C}$ ) and two upflow anaerobic blanket reactors $\left(35\right.$ and $55{ }^{\circ} \mathrm{C}$ ) operated for $470 \mathrm{~d}$ under a hydraulic residence time (HRT) of $2 \mathrm{~d}$. Both anaerobic and aerobic biological treatment reduced the viscosity from $2.02 \mathrm{cp}$ in the influent to $1.45-1.60 \mathrm{cp}$, and reduced the molecular weight of PAM using FFF-MALS from $2.17 \times 10^{7}$ Da to less than one-third its original size. The removals of both the amide group and carbon chain backbone in the PAM molecule were further supported by the FTIR analysis. In comparison with the other conditions, thermophilic anaerobic treatment exhibited higher efficiency for PAM biodegradation. Batch test excluded the influence of temperature on the molecular weight of PAM over the range $25-55^{\circ} \mathrm{C}$, suggesting that cleavage of the main carbon chain backbone was attributed to biological degradation. Our results suggested that high molecular weight PAM was biodegradable, but mineralization did not occur.
\end{abstract}

๑) 2017 Elsevier Ltd. All rights reserved. \footnotetext{
ences, Beijing, 100085, China.

E-mail address: zhangyu@rcees.ac.cn (Y. Zhang).

* Corresponding author. State Key Laboratory of Environmental Aquatic Chemistry, Research Center for Eco-Environmental Sciences, Chinese Academy of Sci-

\section{Introduction}

Partially hydrolyzed anionic polyacrylamide (PAM) with a molecular weight of more than $10^{6} \mathrm{Da}$ and hydrolysis degree of around $25 \%$ (Fig. 1) can increase viscosity and tolerate high mechanical 


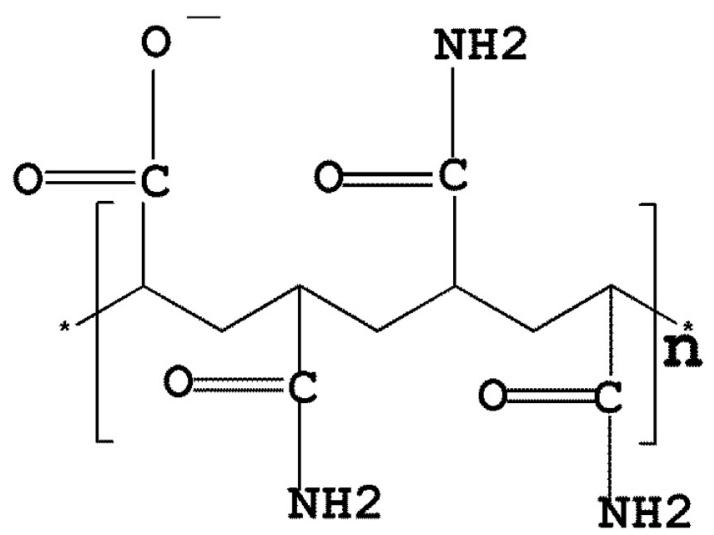

Fig. 1. Molecular structure of high molecular weight partially hydrolyzed polyacrylamide.

forces, and is widely used in oilfields for enhanced oil recovery (EOR) (Wever et al., 2011). To date, 32 pilot and large-scale applications of EOR in China and USA have reported performance data worldwide (Sheng, 2014), with the oil recovery rate increasing by 20\% after adoption of EOR in the Daqing Oilfield, China (Olajire, 2014). Currently, oil recovery accounts for 57\% of PAM consumption in China (Qian, 2010). Due to its high molecular weight and solubility, PAM used during EOR has been considered refractory to biodegradation (Suzuki et al., 1978), and not easily removed from oilfield produced water through conventional treatment (Pi et al., 2015). Thus, many studies have investigated the biodegradability of residual PAM in produced water from the perspective of environmental safety in case of discharge to the natural environment.

It has been reported that PAM biodegradation occurs more easily on the amide side group than cleavage of the main carbon chain backbone (Guezennec et al., 2015; Kay-Shoemake et al., 1998b). PAM can be used as a nitrogen source to stimulate the growth of sulfate-reducing bacteria (Grula and Sewell, 1982; Grula et al., 1994) and methanogens (Haveroen et al., 2005) under anaerobic conditions. In addition, aerobic-mixed bacteria from soil can hydrolyze the amine group of hydrolyzed PAM to release ammonia (Kay-Shoemake et al., 1998a; 1998b).

Although Bacillus sp. (Bao et al., 2010; Wen et al. 2010), Acinetobacter sp. (Matsuoka et al., 2002), and Clostridium sp. (Ma et al., 2010). isolated from oil recovery processes and soil samples reportedly use PAM as sole carbon sources, other studies showed that PAM is unable to serve as the sole carbon source for microbial growth (Chu et al., 2003; Kay-Shoemake et al., 1998a) and that the carbon backbone of PAM would not be cleaved through biological degradation (Haveroen et al., 2005). These contradictory results could relate to the physical properties of the polymers studied (molecular weight, copolymers, degree of hydrolysis, and history) as well as the differences in experimental conditions (Caulfield et al., 2002). The lack of conclusive results and suitable approaches for the characterization of PAM, especially for carbon chain, might also be an important factor affecting the observed biodegradation (Guezennec et al., 2015). To date, solid evidence regarding the cleavage of the main carbon chain backbone of high molecular weight PAM in biological wastewater treatment systems remains limited.

In this study, two suspended aerobic reactors $\left(25\right.$ and $40^{\circ} \mathrm{C}$ ) and two upflow anaerobic blanket reactors ( 35 and $55^{\circ} \mathrm{C}$ ) were constructed and operated for $470 \mathrm{~d}$ to investigate biodegradability of PAM under different conditions. Viscometry, flow field-flow fractionation multi-angle light scattering (FFF-MALS), and attenuated total reflectance-Fourier transform infrared (ATR-FTIR) analysis were used to characterize the molecular weight and functional group change of PAM. The results of this study will hopefully provide important information for the risk assessment and management of PAM in water environments.

\section{Materials and methods}

\subsection{Experimental setup and reactor operation}

The PAM polymer (Table S1) with a nominal molecular weight of $2 \times 10^{7} \mathrm{Da}$ and hydrolysis degree of $24 \%$ was provided by SNF SAS ZAC de Milieux (Andrezieux-42163, France). The molecular weight determined by FFF-MALS was $2.17 \times 10^{7} \mathrm{Da}$, and the viscosity in a $200 \mathrm{mg} / \mathrm{L}$ polymer solution $\left(4 \mathrm{~g} \mathrm{NaCl} / \mathrm{L}, 25^{\circ} \mathrm{C}\right)$ was $2.02 \mathrm{cp}$. Nutrient solution was prepared by dissolving nutrients in tap water at the following composition: starch $24.72 \mathrm{~g} / \mathrm{L}, \mathrm{NH}_{4} \mathrm{Cl}$ $2.87 \mathrm{~g} / \mathrm{L}, \quad \mathrm{NaH}_{2} \mathrm{PO}_{4} 0.48 \mathrm{~g} / \mathrm{L}, \mathrm{NaCl} 240 \mathrm{~g} / \mathrm{L}, \mathrm{HBO}_{3} 50 \mathrm{mg} / \mathrm{L}$, $\mathrm{MnSO}_{4} \cdot 4 \mathrm{H}_{2} \mathrm{O} 40 \mathrm{mg} / \mathrm{L}, \mathrm{ZnSO}_{4} \cdot 7 \mathrm{H}_{2} \mathrm{O} 40 \mathrm{mg} / \mathrm{L}, \mathrm{Na}_{2} \mathrm{MoO}_{4} \cdot 4 \mathrm{H}_{2} \mathrm{O}$ $20 \mathrm{mg} / \mathrm{L}, \mathrm{CuSO}_{4} 5 \mathrm{H}_{2} \mathrm{O} 10 \mathrm{mg} / \mathrm{L}, \mathrm{CoCl}_{2} 10 \mathrm{mg} / \mathrm{L}, \mathrm{KI} 10 \mathrm{mg} / \mathrm{L}$, and $\mathrm{NiCl}_{2} 10 \mathrm{mg} / \mathrm{L}$. The PAM stock solution was prepared by adding $1.2 \mathrm{~g}$ or $2.4 \mathrm{~g}$ of PAM powder into a beaker containing $4 \mathrm{~L}$ of tap water under stirring for $12 \mathrm{~h}$. The solution was then diluted in a bucket containing $8 \mathrm{~L}$ of tap water, and stirred with a mechanical stirrer for $2 \mathrm{~d}$ at $200 \mathrm{rpm}$. Synthetic wastewater was acquired by diluting the nutrient solution $(100 \mathrm{~mL})$ into the bucket, and then used to feed the reactors. Starch was added as a carbon source to promote bacterial growth.

The water-jacketed aerobic reactors had a $2 \mathrm{~L}$ aeration tank and a $0.5 \mathrm{~L}$ sediment tank. Air was supplied to the aeration reactors to provide oxygen and mixing. One reactor was operated at $25 \pm 1{ }^{\circ} \mathrm{C}$ (Aerobic $25^{\circ} \mathrm{C}$ ) and another at $40 \pm 1^{\circ} \mathrm{C}$ (Aerobic $40{ }^{\circ} \mathrm{C}$ ). The two upflow anaerobic sludge blanket reactors, one mesophilic $\left(35 \pm 1{ }^{\circ} \mathrm{C}\right.$, Anaerobic $\left.35{ }^{\circ} \mathrm{C}\right)$ and one thermophilic $\left(55 \pm 1{ }^{\circ} \mathrm{C}\right.$, Anaerobic $55^{\circ} \mathrm{C}$ ), were manufactured with a working volume of $2 \mathrm{~L}$. Activated sludge from the Qinghe Municipal Wastewater Treatment Plant, Beijing, was used as the seed sludge for the aerobic reactors (initial concentration, $2000 \mathrm{mg} / \mathrm{L}$ ), and digestion sludge from the Gaobeidian Municipal Wastewater Treatment Plant, Beijing, was used as the seed sludge for the anaerobic reactors (initial concentration, $2000 \mathrm{mg} / \mathrm{L}$ ). A schematic diagram of the experimental set up is illustrated in Fig. 2.

A HRT of $2 \mathrm{~d}$ was used for the four reactors. The reactors were operated for $470 \mathrm{~d}$ and the whole experiment was divided into two phrases: Phase I with the PAM concentration of $100 \mathrm{mg} / \mathrm{L}$ (from days 0-185) and Phase II with PAM concentration of $200 \mathrm{mg} / \mathrm{L}$ (from days 186-470).

Influent and effluent water samples were taken twice a week after filtration for chemical oxygen demand (COD), PAM concentration, and viscosity analyses. Effluent samples were taken every two to three months for molecular weight analysis, and were kept at $4{ }^{\circ} \mathrm{C}$ after centrifugation. Biomass samples were taken for the measurement of mixed liquor suspended sludge (MLSS).

Sludge samples for microbial community structure analysis were collected on days 183,407 , and 470 , and centrifuged at $10,000 \mathrm{rpm}$ for $10 \mathrm{~min}$ at $4{ }^{\circ} \mathrm{C}$. Genomic DNA was extracted from the samples with a FastDNA ${ }^{\circledR}$ SPIN kit for soil (Qbiogene, Solon, $\mathrm{OH}$, USA) according to the manufacturer's instructions, and then checked by spectrophotometric analysis on a NanoDrop ND-1000 (Nanodrop, USA) and stored at $-20^{\circ} \mathrm{C}$ before use.

The COD, ammonia nitrogen, and MLSS contents were determined according to standard methods (APHA, 2005). Chlorination of the amide nitrogen under acidic conditions forms colloids that can be measured by turbidity method (Scoggins and Miller, 1979). The PAM concentration was measured based on the principle and the brief overview described in supplemental material. The 


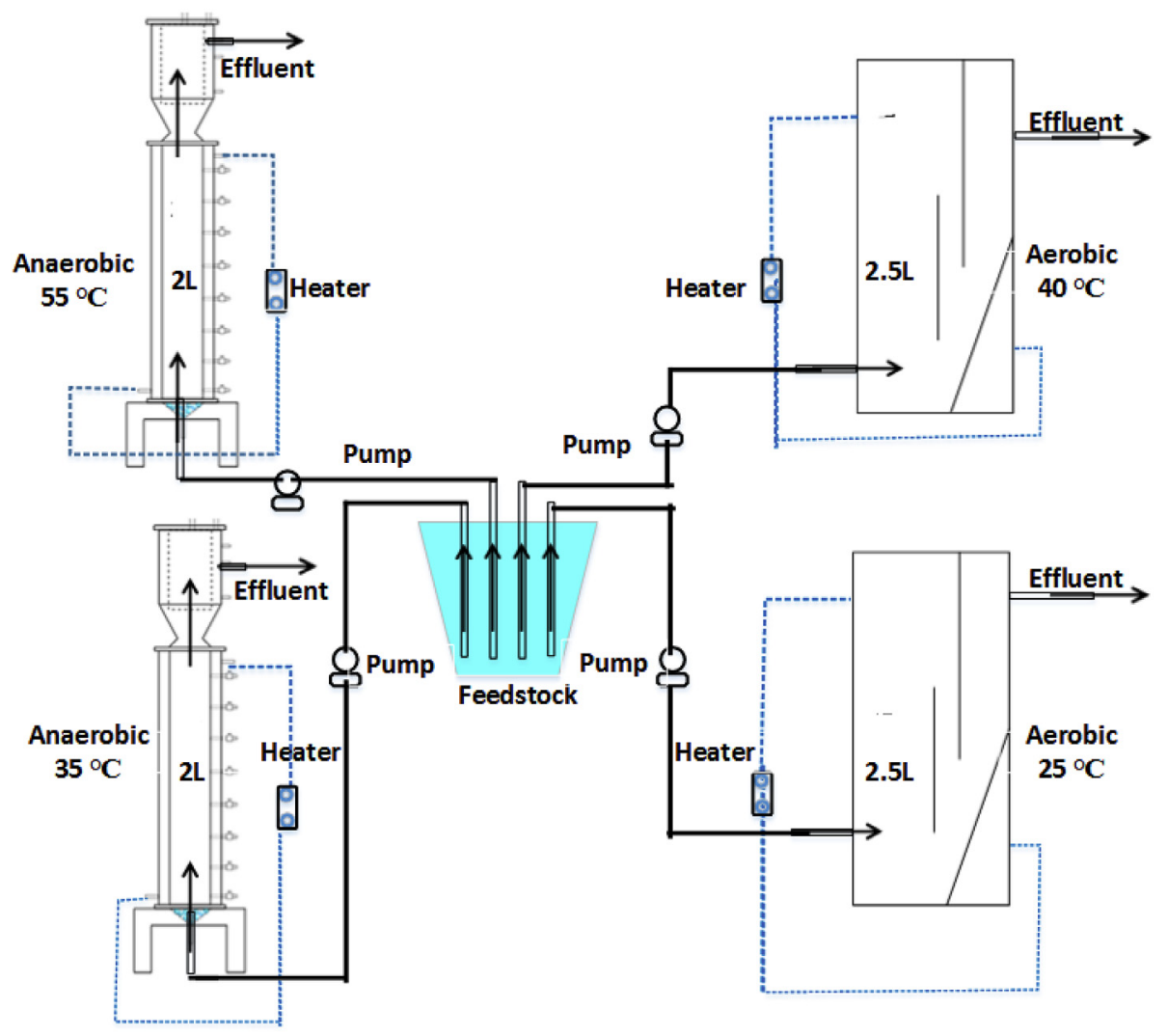

Fig. 2. Schematic diagram of the experimental setup.

viscosity of water was determined on a Brookfield DV3T viscometer at $25^{\circ} \mathrm{C}$. Samples were kept in a $25^{\circ} \mathrm{C}$ bath water for $4 \mathrm{~h}$ to maintain a constant temperature before analysis. All samples were analyzed for chemical properties in triplicate and average values were reported.

\subsection{Batch tests under different temperatures}

Batch test under different temperatures was conducted as a control for abiotic degradation. Conical flasks containing $200 \mathrm{mg} / \mathrm{L}$ of PAM and $4 \mathrm{~g} / \mathrm{L}$ of $\mathrm{NaCl}$ were shaken at $150 \mathrm{rpm}$ under temperatures of $25{ }^{\circ} \mathrm{C}, 35{ }^{\circ} \mathrm{C}, 40{ }^{\circ} \mathrm{C}$, and $55^{\circ} \mathrm{C}$, respectively. After $2 \mathrm{~d}$, samples were analyzed for PAM molecular weight as described above. The experiments were conducted in triplicate.

\subsection{ATR-FTIR analysis}

An ATR-FTIR spectrometer (Avatar 360, Thermo Nicolet, USA) was used to characterize the changes in functional groups. The samples were purified by the dropwise addition of excess methanol to precipitate PAM (Bao et al., 2010; Wen et al. 2010). The precipitated polymer was washed with methanol three times, and then dried to a constant weight under vacuum conditions. The samples were then analyzed by ATR-FTIR.

\subsection{Sludge amidase determination}

Amidase enzyme activity is one of the mechanisms by which amides can be used by bacteria as a source of $\mathrm{N}$ (Kay-Shoemake et al., 1998b). Inoculum for sludge amidase production experiments was obtained by centrifuging $100 \mathrm{~mL}$ of mixed liquor from two aerobic reactors at $2000 \mathrm{rpm}$ for $10 \mathrm{~min}$ at $4{ }^{\circ} \mathrm{C}$, discarding the supernatant and washing the cells three times in $100 \mathrm{~mL}$ of $75 \mathrm{mM}$ phosphate buffer to remove any residual extracellular amidase (Kay-Shoemake et al., 1998a; 1998b). Sludge samples were inoculated into a flask containing $100 \mathrm{~mL}$ of mineral salt medium. Polyacrylamide was provided as the sole carbon and nitrogen source to a concentration of $0.05 \%$ in the medium. The flasks were agitated on a rotary shaker for $2 \mathrm{~d}$ and allowed to settle for $15 \mathrm{~min}$. The supernatant was collected and filtered through a $0.45 \mathrm{~mm}$ filter before analysis of the ammonia concentration. Conventional aerobic sludge grew without PAM was used as the control and PAM solution without sludge was used as the abiotic experiment. The MLSS was measured before the experiment, and amidase was defined as the ratio of ammonia nitrogen concentration to MLSS. The unit of specific enzyme activity should be defined as "unit/mgMLSS".

\subsection{Microbial analysis}

Primers 515 F (5'-GTGCCAGCMGCCGCGG-3') and $907 \mathrm{R}$ (5'-CCGTCAAT TCMTTTRAGTTT-3') for bacteria $16 \mathrm{~S}$ rRNA genes were used to amplifier the genomic DNA ((Li et al., 2009; Parada et al., 2016)). The library was sequenced on an Illumina HiSeq 2500 PE250 platform (Novogene Co., Ltd, Beijing, China) in triplicate. Pairs of reads from the original DNA fragments were merged using FLASH (Magoč and Salzberg, 2011) and then filtered using QIIME software (Caporaso et al., 2010). PCR chimeras were filtered out using UCHIME (http://drive5.com/uchime). The Ribosomal Database Project (RDP) was used to assign taxonomic classification, with the raw reads submitted to the National Center for Biotechnology Information (NCBI) Sequence Read Archive (the accession number was SAMN06626872- 06626966). 


\subsection{Molecular weight analysis}

The flow field-flow fractionation equipment coupled with MALS apparatus (Wyatt Technology Corp., Santa Barbara, CA, USA) was used for analysis of molecular weight. The MALS data were collected at a frequency of $1 \mathrm{~Hz}$ using ASTRA 4.73 (Wyatt Technology Corp., Santa Barbara, CA, USA), and the dn/dc value was fixed at $0.182 \mathrm{~mL} / \mathrm{mg}$ (Leeman et al., 2007). The carrier solution for FFF was deionized water adjusted to a $\mathrm{pH}$ of 3.0 with concentrated hydrochloric acid. The separation channel had a nominal thickness of $250 \mu \mathrm{m}$, and the regenerated cellulose membrane had a $10^{4} \mathrm{Da}$ cutoff. System performance was validated by injecting polyacrylamide standards in the size range $1-9 \times 10^{6} \mathrm{Da}$, which were purchased from the American Polymer Standards Corporation (USA).

The axial flow rate was set to $0.20 \mathrm{~mL} / \mathrm{min}$, and was constant throughout the entire separation, with injection and focusing for $4 \mathrm{~min}$. The transition time from the injection/focusing phase to elution mode was $1 \mathrm{~min}$. Elution started at an initial cross-flow rate of $2.50 \mathrm{~mL} / \mathrm{min}$, but linearly decreased to a final cross-flow rate of 0 in $11 \mathrm{~min}$. After the cross-flow rate reached $0 \mathrm{~mL} / \mathrm{min}$, it was kept at 0 for 16 min to flush out any remaining sample components before the next separation started.

\subsection{Statistical analysis}

Mantel test was done to correlate the change in microbial community and the chemical and physical water variables including the different temperature of operation, PAM concentration, COD, and viscosity. The diversity of sludge samples collected in inoculation, Phase I, and Phase II from four reactors was conducted to cluster the microbial community by principal components analysis (PCA) analysis, and the sludge sample was triplicate. Mantel test and PCA were performed using R 3.1.1 (http://www.rproject.org/). Pearson's correlation and $t$-test were implemented by SPSS 12 . Generally, in this manuscript, $p$ values $<0.05$ are regarded as significant.

\section{Results}

\subsection{Overall performance of the four reactors}

The overall performance of the four reactors is shown in Fig. S1, and the PAM and COD concentrations in the four reactors during the stable periods of Phase I (Days 0-184, inlet PAM concentration $100 \mathrm{mg} / \mathrm{L}$ ) and Phase II (Days 185-490, inlet PAM concentration $200 \mathrm{mg} / \mathrm{L}$ ) are summarized in Table 1 . In Phase I, the COD concentration decreased from $499.5 \mathrm{mg} / \mathrm{L}$ to $162.0,204.9,154.7$, and $166.1 \mathrm{mg} / \mathrm{L}$, and the PAM concentration changed from $94.4 \mathrm{mg} / \mathrm{L}$ to 66.6, 90.8, 74.0, and 73.3 mg/L under Aerobic $25^{\circ} \mathrm{C}$, Aerobic $40^{\circ} \mathrm{C}$, Anaerobic $35{ }^{\circ} \mathrm{C}$, and Anaerobic $55{ }^{\circ} \mathrm{C}$, respectively. The COD/PAM values $(2.43,2.26,2.09$, and 2.31$)$ in the effluent were higher than that in the PAM solution (1.60) which reflected the PAM

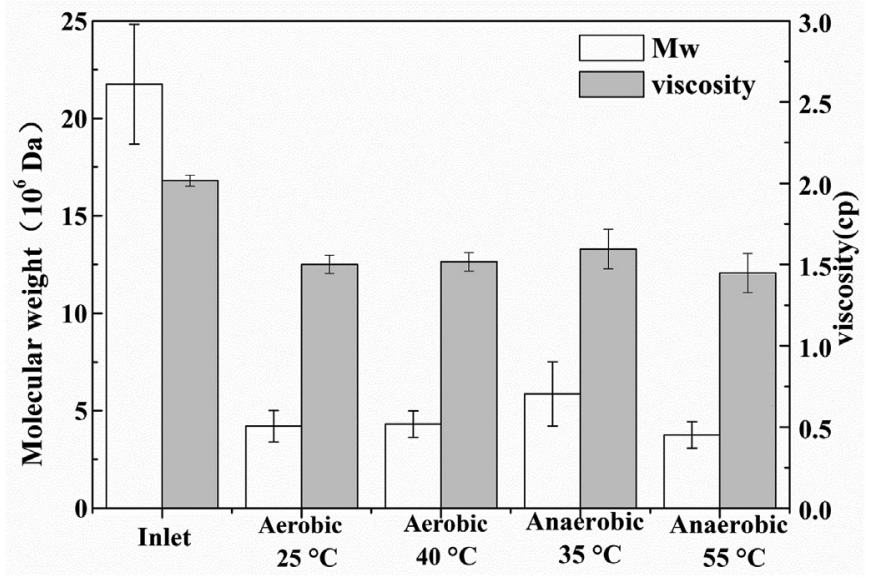

Fig. 3. Changes in molecular weight using FFF-MALS and viscosity before and after biological treatment (PAM concentration, $200 \mathrm{mg} / \mathrm{L}$; results from the stable period of Phase II from Day 410 to Day 470).

concentration decreased faster than COD (Liu et al., 2012). In Phase II, the COD decreased from $619.2 \mathrm{mg} / \mathrm{L}$ to $264.2,272.8,262.4$, and $257.0 \mathrm{mg} / \mathrm{L}$, and the PAM concentration decreased from $207.6 \mathrm{mg} / \mathrm{L}$ to $179.4,188.8,184.2$, and $172.4 \mathrm{mg} / \mathrm{L}$ under aerobic $\left(25\right.$ and $40{ }^{\circ} \mathrm{C}$ ) and anaerobic $\left(35\right.$ and $55^{\circ} \mathrm{C}$ ) treatment, respectively. The COD/PAM values $(1.47,1.45,1.42$, and 1.49$)$ in the effluent were lower than that in the PAM solution (1.60).

Except for Aerobic $40{ }^{\circ} \mathrm{C}$, the reactors exhibited similar COD removal performances in both phases. The Aerobic $40{ }^{\circ} \mathrm{C}$ system exhibited a slightly higher effluent COD concentration due to the occurrence of sludge bulking, as indicated by the high sludge volume index (315 mL/g) and low MLSS (2785 mg/L) values compared with those of Aerobic $25^{\circ} \mathrm{C}(158 \mathrm{ml} / \mathrm{g}$ and $4415 \mathrm{mg} / \mathrm{L}$, respectively). The PAM removal efficiency was not high, varying between $3 \%$ and $9 \%$ in both phases. Microscopic observation indicated that filamentous bacterium Type 0041 (Fig. S2), which is responsible for sludge bulking, was dominant in the activated sludge of the Aerobic $40{ }^{\circ} \mathrm{C}$ reactor (Thomsen et al., 2006).

\subsection{Investigation of the PAM biodegradation}

Changes in viscosity and molecular weight in Phase II are shown in Fig. 3. The starch solution with $0.41 \mathrm{~g} / \mathrm{L}$ will not contribute to viscosity. In the influent, viscosity decreased from $2.02 \mathrm{cp}$ to 1.50 , $1.52,1.60$, and $1.45 \mathrm{cp}$ in the Aerobic $25^{\circ} \mathrm{C}$, Aerobic $40^{\circ} \mathrm{C}$, Anaerobic $35{ }^{\circ} \mathrm{C}$, and Anaerobic $55^{\circ} \mathrm{C}$ reactors, respectively. At the same time, the average molecular weight using FFF-MALS was reduced from $2.17 \times 10^{7} \mathrm{Da}$ in the influent to $4.22 \times 10^{6}, 4.32 \times 10^{6}, 5.87 \times 10^{6}$, and $3.76 \times 10^{6}$ Da in the effluent (Fig. 3 and Fig.S3), respectively. The molecular weight results were in accordance with the viscosity results, and the correlation coefficient was $0.97(p<0.05)$. Both the changes in viscosity and molecular weight indicated that PAM in all

Table 1

PAM concentration and COD in the four reactors during the stable periods of Phases I and II under different inlet PAM concentrations.

\begin{tabular}{|c|c|c|c|c|c|c|}
\hline & Parameter & Inlet & Aerobic $25^{\circ} \mathrm{C}$ & Aerobic $40^{\circ} \mathrm{C}$ & Anaerobic $35^{\circ} \mathrm{C}$ & Anaerobic $55^{\circ} \mathrm{C}$ \\
\hline \multirow[t]{3}{*}{ Phase I (100 mg/L) } & PAM concentration $(\mathrm{mg} / \mathrm{L})$ & $94.4 \pm 10.6$ & $66.6 \pm 9.3$ & $90.8 \pm 12.5$ & $74.0 \pm 8.7$ & $73.3 \pm 8.5$ \\
\hline & $\operatorname{COD}(\mathrm{mg} / \mathrm{L})$ & $499.5 \pm 28.5$ & $162.0 \pm 13.9$ & $204.9 \pm 16.0$ & $154.7 \pm 23.7$ & $169.3 \pm 14.5$ \\
\hline & $\mathrm{COD} / \mathrm{PAM}$ & $1.60^{\mathrm{a}}$ & 2.43 & 2.26 & 2.09 & 2.31 \\
\hline \multirow{3}{*}{ Phase II (200 mg/L) } & PAM concentration $(\mathrm{mg} / \mathrm{L})$ & $207.6 \pm 19.6$ & $179.5 \pm 9.3$ & $188.8 \pm 27.8$ & $184.3 \pm 13.2$ & $172.4 \pm 6.1$ \\
\hline & $\mathrm{COD}(\mathrm{mg} / \mathrm{L})$ & $619.2 \pm 97.6$ & $264.2 \pm 32.0$ & $272.8 \pm 35.3$ & $262.4 \pm 25.2$ & $257.0 \pm 19.8$ \\
\hline & $\mathrm{COD} / \mathrm{PAM}$ & $1.60^{\mathrm{a}}$ & 1.47 & 1.45 & 1.42 & 1.49 \\
\hline
\end{tabular}

\footnotetext{
a Empirical value of the initial PAM sample.
} 
four systems was degraded to some extent. The results of Anaerobic $35^{\circ} \mathrm{C}$ was statistically different with other three reactors $(p<0.05)$, and the Anaerobic $55^{\circ} \mathrm{C}$ system was the most efficient in regards to the degradation of PAM. Batch test results of molecular weight changes under different temperatures was conducted as a control for abiotic degradation are shown in Table 2. The average molecular weights of PAM were $1.97 \times 10^{7}, 1.97 \times 10^{7}, 1.98 \times 10^{7}$, and $1.97 \times 10^{7} \mathrm{Da}$, respectively, after the PAM solutions were shaken at $25,35,40$, and $55^{\circ} \mathrm{C}$ for $2 \mathrm{~d}$, which were the same as that observed in the control $\left(1.98 \times 10^{7} \mathrm{Da}\right)$.

The ATR-FTIR spectra before and after biological treatment are shown in Fig. 4. Three bands at $3400 \mathrm{~cm}^{-1}, 2815 \mathrm{~cm}^{-1}$, and $1615 \mathrm{~cm}^{-1}$, representing the $-\mathrm{NH} 2,-\mathrm{CHR}-\mathrm{CHR}-$, and $-\mathrm{C}=\mathrm{O}$ groups of PAM, respectively (Bao et al., 2010; Wen et al. 2010), were identified in all samples. After biological treatment, the bands at $3400 \mathrm{~cm}^{-1}$ and $1615 \mathrm{~cm}^{-1}$ reduced markedly, particularly for the Anaerobic $55^{\circ} \mathrm{C}$ and Aerobic $25^{\circ} \mathrm{C}$ samples, which could be due to the occurrence of hydrolysis of the amide group. The band at $2815 \mathrm{~cm}^{-1}$ also weakened after biodegradation, suggesting the possible breakdown of the PAM carbon backbone.

The specific amidase activities of the Aerobic $25^{\circ} \mathrm{C}$ and Aerobic $40{ }^{\circ} \mathrm{C}$ systems were 0.148 and 0.123 unit/mg-MLSS, respectively. Conventional aerobic sludge grew without PAM was used as the control treating wastewater without PAM did not produce the amidase enzyme. The detection of this enzyme suggests that aerobic sludge in the two aerobic systems had the ability to cleave the $\mathrm{C}-\mathrm{N}$ bond of PAM. The detection of this enzyme suggests that aerobic sludge in the two aerobic systems had the ability to cleave the $\mathrm{C}-\mathrm{N}$ bond of PAM. It should be noted that $\mathrm{C}-\mathrm{N}$ bond is the side functional group on PAM backbone. The cleavage of the $\mathrm{C}-\mathrm{N}$ bond released the ammonia from the side chain, but it should not shorten the polymer chain (that requires $\mathrm{C}-\mathrm{C}$ bond cleavage).

\subsection{Microbial community composition}

Sequencing analysis was performed to determine the microbial population at the phylum and genus levels for sludge samples from the four reactors in both phases. In total, 60,670 high-quality bacterial reads (average length of $373 \mathrm{bp}$ ) were generated by PCR amplicons. The Shannon diversity index indicated the microbial community diversity, and higher value represents higher diversity. The Shannon diversity index for Aerobic $25^{\circ} \mathrm{C}$, Aerobic $40{ }^{\circ} \mathrm{C}$, Anaerobic $35^{\circ} \mathrm{C}$, and Anaerobic $55^{\circ} \mathrm{C}$ changed from 5.64, 4.74, 5.96, and 3.76 on day 183 in Phase I to 6.11, 5.61, 5.65, and 5.35, respectively, in Phase II.

As shown in Fig. S4, the Aerobic $25^{\circ} \mathrm{C}$ reactor in Phases I and II was dominated by Bacteroidetes (51.2\% and 39.3\%), Proteobacteria (30.4\% and 28.7\%), and Planctomycetes (5.8\% and 11.6\%) at the phylum level. The Aerobic $40{ }^{\circ} \mathrm{C}$ reactor was also dominated by Bacteroidetes (56.7\% and $11.2 \%$ ), Proteobacteria (18.1\% and $27.2 \%$ ), and Planctomycetes (16.0\% and 21.4\%), as well as Chloroflexi (30.5\%), which became dominant in Phase II. The Anaerobic $35^{\circ} \mathrm{C}$ reactor was dominated by Chloroflexi (63.3-67.9\%) in both phases, whereas the Anaerobic $55{ }^{\circ} \mathrm{C}$ reactor was dominated by Chloroflexi (14.6-26.9\%), Proteobacteria (11.9-19.0\%), Bacteroidetes (15.5-22.6\%), and OP8 (28.7-30.4\%).

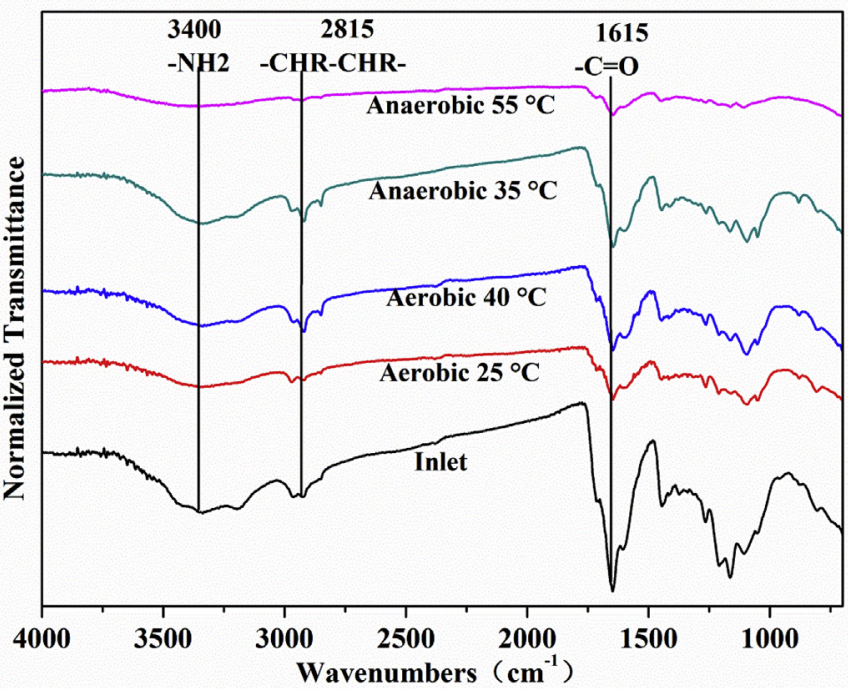

Fig. 4. ATR-FTIR spectra before and after biological treatment (Day 470).

The Aerobic $25{ }^{\circ} \mathrm{C}$ system in Phase I exhibited diverse genera, including Methylibium (4.6\%), Flavobacterium (4.4\%), and Planctomyces (1.6\%), with Flavobacterium (17.7\%), Dok59 (14.0\%), Planctomyces (2.8\%), and Luteolibacter (2.4\%) becoming dominant in Phase II. The Aerobic $40{ }^{\circ} \mathrm{C}$ system was dominated by Planctomyces $(9.1 \%$ and $5.35 \%$ ) and Caldilinea (2.5\% and 22.65\%) in Phases I and II. The dominant bacterial genera in the Anaerobic $35{ }^{\circ} \mathrm{C}$ system were Bacteroides (8.7\%), Anaerolinea (5.3\%), T78 (3.6\%), Longilinea (2.5\%), and Syntrophobacter (2.3\%) in Phase I, and Bacteroides (19.59\%) and C1_B004 (1.73\%) in Phase II. The Anaerobic $55{ }^{\circ} \mathrm{C}$ reactor was dominated by Anaerolinea (54.9\%) and Paludibacter (2.3\%) in Phase I, and Anaerolinea (12.18\%) and Paludibacter (1.58\%) in Phase II. In this study, starch was added to the substrate as a carbon source to support bacterial growth. The dominance of Caldilinea, Dok59, and Flavobacterium in the aerobic systems, and Bacteroides, Anaerolinea, and Bellilinea in the anaerobic systems was likely associated with the hydrolysis of starch (Li et al., 2015; Tian et al., 2015; Xin et al., 2016; Zhou et al., 2014).

Mantel test was tried to examine the relationship between the diversity of microbial community and the temperature of operation, and the results showed there was significant correlation $(p<0.05)$ (Table S2). PCA was conducted to cluster the microbial community of sludge samples collected from the four reactors, and the distribution was divided into six different groups (Fig. S5). The result further reflected that the temperature have a significant effect on the change of microbial community.

\section{Discussion}

Although many studies have reported on the occurrence of biodegradation of PAM (Caulfield et al., 2002; Guezennec et al., 2015; Sang et al., 2015), solid evidence regarding the cleavage of the main carbon chain backbone of high molecular weight PAM in

Table 2

Batch experiment results of changes in molecular weight under different temperatures.

\begin{tabular}{|c|c|c|c|c|c|}
\hline & Control $^{\mathrm{a}}$ & $25^{\circ} \mathrm{C}$ & $35^{\circ} \mathrm{C}$ & $40^{\circ} \mathrm{C}$ & $55^{\circ} \mathrm{C}$ \\
\hline PAM concentration $(\mathrm{mg} / \mathrm{L})$ & $198.7 \pm 0.7$ & $199.2 \pm 0.6$ & $199.2 \pm 0.5$ & $199.2 \pm 0.7$ & $199.2 \pm 0.8$ \\
\hline Viscosity (cp) & $2.03 \pm 0.02$ & $1.99 \pm 0.01$ & $1.98 \pm 0.02$ & $1.98 \pm 0.02$ & $1.97 \pm 0.01$ \\
\hline Molecular weight $\left(10^{7} \mathrm{Da}\right)$ & $1.98 \pm 0.02$ & $1.97 \pm 0.03$ & $1.98 \pm 0.02$ & $1.97 \pm 0.04$ & $1.97 \pm 0.05$ \\
\hline
\end{tabular}

\footnotetext{
${ }^{\text {a }}$ Control was operated without shaking at room temperature around $25{ }^{\circ} \mathrm{C}$ for $2 \mathrm{~d}$.
} 
biological wastewater treatment systems is limited. In this study, all of the results acquired through the FFF-MALS, ATR-FTIR and viscometer analyses directed to the cleavage of the carbon chain backbone of PAM with a nominal molecular weight as high as $2 \times 10^{7}$ Da during anaerobic and aerobic treatment.

FFF is considered effective in separating polymers with high molecular weights (Hecker et al., 1999), and its coupling with MALS has been successfully used for the determination of PAM over $1.80 \times 10^{7}$ Da (Leeman et al., 2007). By using FFF-MALS, we successfully revealed the degradation of PAM with a molecular weight of $2.17 \times 10^{7}$ Da in inlet (Fig. S6). The molecular weight of PAM was reduced to less than one-third of its original size, from $2.17 \times 10^{7} \mathrm{Da}$ to $3.76-5.87 \times 10^{6} \mathrm{Da}$, suggesting the cleavage of the carbon chain backbone. In addition, although the size exclusion chromatography (SEC) method can only be used for the determination of polymers with a molecular weight below $10^{7}$ Da due to the influence of shear degradation, adsorption, and accurate pore-size distribution (Leeman et al., 2007), Fig. S7 showed that new peak of lower molecular weight products $\left(\mathrm{M}_{\mathrm{W}}\right.$ below $6 \times 10^{6} \mathrm{Da}$, retention times 22-26 min) in the effluent than that of the inlet was detected in the SEC spectrum, further supporting the degradation of PAM. At the same time, viscosity decreased from $2.02 \mathrm{cp}$ in the influent to $1.45-1.60 \mathrm{cp}$ after biological treatment (Fig. 3). The change in molecular weight was in accordance with that of viscosity, with a correlation coefficient of $0.97(p<0.05)$, suggesting that the change in viscosity was mainly attributable to the reduction in molecular size (Sukpisan et al., 1998). The band of -CHR-CHR-group from FTIR at Aerobic 25 and Anaerobic $55^{\circ} \mathrm{C}$ (Fig. 4) also weakened markedly after biodegradation, suggesting the possible breakdown of the PAM carbon backbone, which corresponded with the significant reduction in molecular weight and viscosity.

PAM has been reportedly broken down by physical-chemical factors, including sunlight, chemical, mechanical, and thermal degradation (Caulfield et al., 2002; El-Mamouni et al., 2002). Since the Anaerobic $55^{\circ} \mathrm{C}$ system was most efficient in the degradation of PAM (Fig. 4), the impact of temperature on changes in PAM molecular size was investigated via batch tests. As shown in Table 2, the increase in temperature did not lead to a change in PAM size after $2 \mathrm{~d}$. It has been reported that the molecular weight of PAM $\left(2.90 \times 10^{6} \mathrm{Da}\right)$ only changed slightly after maintaining the solutions at $50{ }^{\circ} \mathrm{C}$ for $5 \mathrm{~d}$ (Kurenkov et al., 2002). This supports that the reduction in molecular weight of PAM was mainly caused by microbial degradation.

On the other hand, the hydrolysis of the amide group in PAM has often been reported during biological degradation studies (Haveroen et al., 2005; Kay-Shoemake et al., 1998a; Grula and Sewell, 1982). In this study, the reduction in the $-\mathrm{NH}_{2}$ and $-\mathrm{C}=\mathrm{O}$ band intensity was also observed, which was in accordance with previous studies (Bao et al., 2010; Wen et al. 2010). The PAM removal $(9 \%-17 \%)$ might be associated with the hydrolysis of the amide group, and concentration of PAM was doubled in Phase II of operation may contribute to the extent of PAM degradation. It has been reported that PAM oligomers over $3 \times 10^{6}$ Da cannot be assimilated by microorganisms (Kay-Shoemake et al., 1998a). Thus, the destruction of the amide group might be associated with extracellular enzymes, as evidenced by the amidase activity in the Aerobic $25{ }^{\circ} \mathrm{C}$ and Aerobic $40{ }^{\circ} \mathrm{C}$ systems. The amidase enzyme belongs to the family of hydrolases that catalyze the cleavage of the carbon-nitrogen bond of monocarboxylic acid amides to form monocarboxylic acid and ammonia nitrogen (Kay-Shoemake et al., 1998a; 1998b). The reported amidase enzyme producing genera, for example Klebsiella, Mycobacterium, Agrobacterium, Stenotrophomonas, Comamonas, Xanthobacter, Rhodococcus, Pseudonocardia, Brevibacillus, Corynebacterium, and Nocardia (Bhalla, 2009), were also detected in the sludge samples of four reactors in this study (Table S3).

It should be noted that although high molecular weight PAM might be biodegradable, however, the degradation efficiency of PAM was very low. The reason may be the protection of the molecular structure containing amide group (Suzuki et al., 1978). On the other hand, inlet PAM with high molecular weight is unable to pass the microbial membranes (Guezennec et al., 2015). Previous study has shown that molecular weights above $3 \times 10^{3}$ Da was recalcitrant to microbial mineralization (El-Mamouni et al., 2002). Previous study has shown that molecular weights above $3 \times 10^{3} \mathrm{Da}$ are recalcitrant to microbial mineralization (El-Mamouni et al., 2002). In addition, although Bacillus (Bao et al., 2010), Acinetobacter (Matsuoka et al., 2002), Pseudomonas (Yu et al., 2015), and Clostridium (Ma et al., 2010) grew in the four reactors, their abundances were low. Thus, further studies are required to investigate the mineralization conditions of PAM.

\section{Conclusions}

Multiple approaches were employed to characterize the changes in PAM with a nominal molecular weight as high as $2 \times 10^{7}$ Da during anaerobic and aerobic treatment. All of the results acquired through the FFF-MALS, ATR-FTIR and viscometer analyses directed to the cleavage of the carbon chain backbone of PAM under aerobic and anaerobic conditions with a HRT of $2 \mathrm{~d}$. In comparison with other conditions, thermophilic anaerobic treatment exhibited slightly higher efficiency for the degradation of PAM.

\section{Acknowledgments}

This study was supported by the Ministry of Science and Technology, People's Republic of China (2012AA063401).

\section{Appendix A. Supplementary data}

Supplementary data related to this article can be found at http:// dx.doi.org/10.1016/j.chemosphere.2017.09.079.

\section{References}

APHA, 2005. Standard Methods for the Examination of Water and Wastewater. American Public Health Association, Washington, DC.

Bao, M.T., Chen, Q.G., Li, Y.M., Jiang, G.C., 2010. Biodegradation of partially hydrolyzed polyacrylamide by bacteria isolated from production water after polymer flooding in an oil field. J. Hazard Mater 184 (1-3), 105-110. http://dx.doi.org/ 10.1016/j.jhazmat.2010.08.011.

Bhalla, M.S.N.N.S.T.C., 2009. Amidases: versatile enzymes in nature. Rev. Environ. Sci. Biotechnol. 8, 343-366. http://dx.doi.org/10.1007/s11157-009-9175-X.

Caporaso, J.G., Kuczynski, J., Stombaugh, J., Bittinger, K., Bushman, F.D., Costello, E.K., Fierer, N., Pena, A.G., Goodrich, J.K., Gordon, J.I., Huttley, G.A., Kelley, S.T., Knights, D., Koenig, J.E., Ley, R.E., Lozupone, C.A., McDonald, D., Muegge, B.D., Pirrung, M., Reeder, J., Sevinsky, J.R., Turnbaugh, P.J., Walters, W.A., Widmann, J., Yatsunenko, T., Zaneveld, J., Knight, R., 2010. QIIME allows analysis of highthroughput community sequencing data. Nat. Methods 7 (5), 335-336. http://dx.doi.org/10.1038/nmeth.f.303.

Caulfield, M.J., Qiao, G.G., Solomon, D.H., 2002. Some aspects of the properties and degradation of polyacrylamides. Chem. Rev. 102 (9), 3067-3083. http:// dx.doi.org/10.1002/chin.200244274.

Chu, C.P., Lee, D.J., Chang, B.V., You, C.H., Liao, C.S., Tay, J.H., 2003. Anaerobic digestion of polyelectrolyte flocculated waste activated sludge. Chemosphere 53 (7), 757-764. http://dx.doi.org/10.1016/S0045-65 35(03) 0055-0058.

El-Mamouni, R., Frigon, J.C., Hawari, J., Marroni, D., Guiot, S.R., 2002. Combining photolysis and bioprocesses for mineralization of high molecular weight polyacrylamides. Biodegradation 13 (4), 221-227. http://dx.doi.org/10.1023/A: 1021272519714.

Grula, M., Sewell, G., 1982. Polyacrylamide stimulation of desulfovbrio growth and sulfate reduction. Dev. Ind. Microbiol. 23, 419-424.

Grula, M.M., Huang, M.L., Sewell, G., 1994. Interactions of certain polyacrylamides with soil bacteria. Soil Sci. 158 (4), 291-300. http://dx.doi.org/10.1097/ 00010694-199410000-00009.

Guezennec, A.G., Michel, C., Bru, K., Touze, S., Desroche, N., Mnif, I., Motelica- 
Heino, M., 2015. Transfer and degradation of polyacrylamide-based flocculants in hydrosystems: a review. Environ. Sci. Pollut. Res. Int. 22 (9), 6390-6406. http://dx.doi.org/10.1007/s11356-014-3556-6.

Haveroen, M.E., MacKinnon, M.D., Fedorak, P.M., 2005. Polyacrylamide added as a nitrogen source stimulates methanogenesis in consortia from various wastewaters. Water Res. 39 (14), 3333-3341. http://dx.doi.org/10.1016/j.watres. 2005.05.042.

Hecker, R., Fawell, P.D., Jefferson, A., Farrow, J.B., 1999. Flow field-flow fractionation of high-molecular-mass polyacrylamide. J. Chromatog. A 837 (1-2), 139-151. http://dx.doi.org/10.1016/S0021-9673(99)00070-9.

Kay-Shoemake, J.L., Watwood, M.E., Lentz, R.D., Sojka, R.E., 1998a. Polyacrylamide as an organic nitrogen source for soil microorganisms with potenial effects on inorganic soil nitrogen in agricultural soil. Soil Biol. Biochem. 30 (8-9), 1045-1052. http://dx.doi.org/10.1016/S0038-0717(97)00250-2.

Kay-Shoemake, J.L., Watwood, M.E., Sojka, R.E., Lentz, R.D., 1998b. Polyacrylamide as a substrate for microbial amidase in culture and soil. Soil Biol. Biochem. 30 (13), 1647-1654. http://dx.doi.org/10.1016/S0038-0717(97)0025 1-4.

Kurenkov, V.F., Hartan, H.G., Lobanov, F.I., 2002. Degradation of polyacrylamide and its derivatives in aqueous solutions. Russ. J. Appl. Chem. 75 (7) http://dx.doi.org/ 1039-1050. 10.1023/A:1020747523268.

Leeman, M., Islam, M.T., Haseltine, W.G., 2007. Asymmetrical flow field-flow fractionation coupled with multi-angle light scattering and refractive index detections for characterization of ultra-high molar mass poly(acrylamide) flocculants. J. Chromatog. A 1172 (2), 194-203. http://dx.doi.org/10.1016/j. chroma.2007.10.006.

Li, C., Zhang, Z., Li, Y., Cao, J., 2015. Study on dyeing wastewater treatment at high temperature by MBBR and the thermotolerant mechanism based on its microbial analysis. Process Biochem. 50 (11), 1934-1941. http://dx.doi.org/10.1016/ j.procbio.2015.08.007. http://dx.doi.org/.

Li, H., Zhang, Y., Li, D., Xu, H., Chen, G., Zhang, C., 2009. Comparisons of different hypervariable regions of rrs genes for fingerprinting of microbial communities in paddy soils. Soil Biol. Biochem. 41 (5), 954-968. http://dx.doi.org/10.1016/ j.soilbio.2008.10.030.

Liu, L., Wang, Z., Lin, K., Cai, W., 2012. Microbial degradation of polyacrylamide by aerobic granules. Environ. Technol. 33 (7-9), 1049-1054. http://dx.doi.org/ 10.1080/09593330.2011.606846.

Ma, Y., Yu, H., Pan, W., Liu, C., Zhang, S., Shen, Z., 2010. Identification of nitrile hydratase-producing Rhodococcus ruber $\mathrm{TH}$ and characterization of an amiEnegative mutant. Bioresour. Technol. 101 (1), 285-291. http://dx.doi.org/ 10.1016/j.biortech.2009.07.057.

Magoč, T., Salzberg, S.L., 2011. FLASH: fast length adjustment of short reads to improve genome assemblies. Bioinformatics 27 (21), 2957-2963. http:// dx.doi.org/10.1093/bioinformatics/btr507.

Matsuoka, H., Hikuma, M., Ishimura, F., Takeda, T., 2002. Isolation of polyacrylamide-degrading microorganisms from soil. Biotechnol. Bioproc. E 7 (5), 327-330. http://dx.doi.org/10.1007/BF02932844.

Olajire, A.A., 2014. Review of ASP EOR (alkaline surfactant polymer enhanced oil recovery) technology in the petroleum industry:Prospects and challenges. Energy 77, 963-982. http://dx.doi.org/10.1016/j.energy.2014.09.005.

Parada, A.E., Needham, D.M., Fuhrman, J.A., 2016. Every base matters: assessing small subunit rRNA primers for marine microbiomes with mock communities, time series and global field samples. Environ. Microbiol. 18 (5), 1403-1414. http://dx.doi.org/10.1111/1462-2920.13023.

Pi, Y., Zheng, Z., Bao, M., Li, Y., Zhou, Y., Sang, G., 2015. Treatment of partially hydrolyzed polyacrylamide wastewater by combined fenton oxidation and anaerobic biological processes. Chem. Eng. J. 273, 1-6. http://dx.doi.org/ 10.1016/j.cej.2015.01.034.

Qian, B., 2010. Process technology and market analysis of polyacrylamide. Chemical Industry, Z1, 15-19 (Chinese).

Sang, G., Pi, Y., Bao, M., Li, Y., Lu, J., 2015. Biodegradation for hydrolyzed polyacrylamide in the anaerobic baffled reactor combined aeration tank. Ecol. Eng. 84, 121-127. http://dx.doi.org/10.1016/j.ecoleng.2015.07.028.

Scoggins, M.W., Miller, J.W., 1979. Determination of water-soluble polymers containing primary amide groups using the starch-triiodide method. Soc. Pet. Eng. J. 19 (3), 151-154. http://dx.doi.org/10.2118/7664-PA.

Sheng, J.J., 2014. A comprehensive review of alkaline-surfactant-polymer (ASP) flooding. Asia Pac. J. Chem. Eng. 9 (4), 471-489. http://dx.doi.org/10.1002/ apj.1824.

Sukpisan, J., Kanatharana, J., Sirivat, A., Wang, S.Q., 1998. The specific viscosity of partially hydrolyzed polyacrylamide solutions: effects of degree of hydrolysis, molecular weight, solvent quality and temperature. J. Polym. Sci. Part B Polym. Phys. 36 (5), 743-753. http://dx.doi.org/10.1002/(SICI) 1099-0488 (19980415) 36:5<743::AID-POLB2>3.0.CO;2-M.

Suzuki, J., Hukushima, K., Suzuki, S., 1978. Effect of ozone treatment upon biodegradability of water-soluble polymers. Environ. Sci. Technol. 12 (10), 1180-1183. http://dx.doi.org/10.1021/es60146a002.

Thomsen, T.R., Kragelund, C., Nielsen, P.H., 2006. Identity, abundance and physiology of Aquaspirillum-related filamentous bacteria in activated sludge. Water Sci. Technol. 54 (1), 237-245. http://dx.doi.org/10.2166/wst.2006.392.

Tian, Z., Zhang, Y., Li, Y., Chi, Y., Yang, M., 2015. Rapid establishment of thermophilic anaerobic microbial community during the one-step startup of thermophilic anaerobic digestion from a mesophilic digester. Water Res. 69, 9-19. http:// dx.doi.org/10.1016/j.watres.2014.11.001.

Wen, Q., Chen, Z., Zhao, Y., Zhang, H., Feng, Y., 2010. Biodegradation of polyacrylamide by bacteria isolated from activated sludge and oil-contaminated soil. J. Hazard Mater 175 (1-3), 955-959. http://dx.doi.org/10.1016/j. jhazmat. 2009.10.102.

Wever, D.A.Z., Picchioni, F., Broekhuis, A.A., 2011. Polymers for enhanced oil recovery:A paradigm for structure-property relationship in aqueous solution. Prog. Polym. Sci. 36 (11), 1558-1628. http://dx.doi.org/10.1016/j. progpolymsci. 2011.05.006.

Xin, X., He, J., Wang, Y., Feng, J., Qiu, W., 2016. Role of aeration intensity on performance and microbial community profiles in a sequencing batch reaction kettle (SBRK) for wastewater nutrients rapid removal. Bioresour. Technol. 201, 140-147. http://dx.doi.org/10.1016/j.biortech.2015.11.053.

Yu, F., Fu, R.M., Xie, Y., Chen, W.L., 2015. Isolation and characterization of polyacrylamide-degrading bacteria from dewatered sludge. Int. J. Env. Res. Pub. He 12 (4), 4214-4230. http://dx.doi.org/10.3390/ijerph120404214.

Zhou, Z., Oiao, W., Xing, C., Shen, X., Hu, D., Wang, L., 2014. A micro-aerobic hydrolysis process for sludge in situ reduction: performance and microbial community structure. Bioresour. Technol. 173, 452-456 http://dx.doi.org/10.10 16/ j.biortech.2014.09.119. 